\title{
Chemical Analysis and Antimicrobial Effect of Propolis from Hakkari Province of Turkey against Some Pathogenic Microorganisms
}

\section{Sinan Bayram ${ }^{1}$, Nesrin Ecem Bayram²,3*, Yusuf Can Gercek ${ }^{4}$, Mehmet Nuri Aydogan5, Gul Cevahir Oz ${ }^{4}$}

'Bayburt University, Vocational School of Health Services, Department of Medical Services and Techniques, Bayburt, Turkey Bayburt University, Aydıntepe Vocational College, Department of Food Processing, Bayburt, Turkey ${ }^{3}$ Bayburt University, Beekeeping Research, Development and Application Center, Bayburt, Turkey ${ }^{4}$ Istanbul University, Faculty of Sciences, Department of Biology, Istanbul, Turkey ${ }^{5}$ Ataturk University, Faculty of Sciences, Department of Biology, Erzurum, Turkey

Please cite this article as: Bayram S, Ecem Bayram N, Gercek YC, Aydogan MN, Cevahir Oz G. Chemical Analysis and Antimicrobial Effect of Propolis from Hakkari Province of Turkey against Some Pathogenic Microorganisms. Eur J Biol 2017; 76(2): 74-8

\begin{abstract}
This study was performed to investigate the antimicrobial effect of propolis from Hakkari province of Turkey and its chemical content by Gas Chromatography-Mass Spectroscopy. In vitro inhibitory activity of propolis was studied by the disc diffusion method against six gram positive, three gram negative bacteria and one yeast like fungi. As a result of chemical analysis, the total flavonoid ratio of the propolis sample was found to be higher than the other compound groups. Pinostrobin chalcone, pinocembrin and chrysin were identified as major flavonoids. Also, all microorganisms tested were susceptible to the propolis extract except for Klebsiella pneumoniae. Minimum inhibition concentration (MIC) values were determined by microbroth dilution assay. MIC values against microorganisms ranged from 25 to $200 \mu \mathrm{g} / \mathrm{mL}$. Antimicrobial susceptibility test results showed that inhibitory effect our propolis sample was somewhat weaker than ampicillin, but it had a broader spectrum.
\end{abstract}

Keywords: Ampicillin, antimicrobial effect, minimum inhibition concentration (MIC), propolis content

\section{INTRODUCTION}

Natural products present a large variety of biological and pharmacological activities and are considered to have beneficial effects in human nutrition (1). In recent years focus on natural products and alternative medicines has renewed interest in bee products such as honey, royal jelly, pollen, and propolis (2).

Propolis is a natural resinous complex collected from different plants by bees. Due to its healing properties, propolis has been used in traditional medicine as an antiseptic, wound healer and therapeutic substance from ancient times to the present (3). Existing studies suggest that propolis, when used as a nutritional supplement, is very important in protecting human health due to its biochemical and biopharmaceutical substances (4). Chemical substances in propolis are generally waxes, resins, balms, aromatic oils, pollen, flavonoids, terpenoids and other organic substances (5). Both the biological activity of propolis as antibacterial, antiviral, antioxidative, antifungal and antiatherogenic, antiproliferative, proapoptotic, antienflamatuar, cytotoxic, and the presence and proportion of bioactive substances in it varies by the phytogeographic properties of the area in which the samples are collected (6-9).

Along with the rising interest in natural products, propolis has been a promising source for discovering new drugs (10). For this reason, propolis has been extensively studied especially due to its chemical structure and biological properties in recent years $(11,12)$. The aim of this study was to investigate the antimicrobial effect of propolis from Hakkari province of Turkey and its chemical composition. 


\section{MATERIALS AND METHODS}

\section{Extraction of Propolis}

The propolis sample was gathered from Hakkari province of Turkey. The sample was frozen in the freezer $\left(-18^{\circ} \mathrm{C}\right)$ and then disintegrated with a grinder and $30 \mathrm{~g}$ of the powdered propolis sample was dissolved in $90 \mathrm{ml}$ of $96 \%$ ethanol. This mixture was incubated for two weeks at $30{ }^{\circ} \mathrm{C}$ in a tightly closed dark colored bottle. After two weeks, the supernatant was filtered twice with Whatman No. 4 and No.1 filter papers, respectively. The final solution was diluted in 1:10 ratio $(\mathrm{w} / \mathrm{v})$ with ethanol (96\%). A portion of this final solution was evaporated to obtain completely dry sample. About $5 \mathrm{mg}$ of dry substance was mixed with $75 \mu \mathrm{l}$ of dry pyridine and $50 \mu \mathrm{l}$ bis (trimethylsilyl) trifluoroacetamide heated at $80^{\circ} \mathrm{C}$ for $20 \mathrm{~min}$ and then supernatant was analyzed by gas chromatography-mass ppectroscopy (GC-MS) (13).

\section{GC-MS Analysis}

The gas GC-MS analyses conducted at the Environment and Instrumental Laboratory of Istanbul University using an Agilent brand GC (model 7890A) and MS (model 5975C) equipped with a mass selection detector. The GC was equipped with a (5\%-phenyl)-methyl polysiloxane DB-5MS column (30 m length $\times 0.25 \mathrm{~mm}$ i.d. $\times 0.25 \mu \mathrm{m} \mathrm{df}$ ) and an Agilent automatic injection system. The chromatogram was produced by holding the oven temperature at $35^{\circ} \mathrm{C}$ for $8 \mathrm{~min}$ initially and then increasing the temperature to $60{ }^{\circ} \mathrm{C}$ at a rate of $6{ }^{\circ} \mathrm{C} / \mathrm{min}$ followed by an increase at a rate of $4{ }^{\circ} \mathrm{C} / \mathrm{min}$ to $160^{\circ} \mathrm{C}$ and $20^{\circ} \mathrm{C} / \mathrm{min}$ to $200^{\circ} \mathrm{C} /$ min and kept at $200^{\circ} \mathrm{C}$ for 1 min at which it was held for $1 \mathrm{~min}$ (14). Helium was used as the carrier gas at a flow rate of $0.7 \mathrm{~mL} /$ min. Split ratio $1: 80$, injector temperature $280{ }^{\circ} \mathrm{C}$, ionization voltage $70 \mathrm{eV}$. Identification of components in propolis extract was carried out with the WILEY-NIST MS data library.

\section{Test Microorganisms}

In this study, six gram positive bacteria (Staphylococcus aureus NCTC 10788, Staphylococcusepidermidis, Corynebacterium diphtheria, Enterococcus faecalis NCTC 12697, Bacillus cereus ATCC 10876, Bacillus subtilis); three gram negative bacteria (Escherichia coli NCTC 9001, Klebsiella pneumonia, Pseudomonas aeruginosa NCTC 12924) and one yeast like fungi (Candida albicans ATCC 10231) were used for determination of antimicrobial activity of propolis. All microorganisms were provided by the Department of Medical Services and Techniques, Vocational School of Health Services, Bayburt University.

Bacterial strains were cultured overnight at $37^{\circ} \mathrm{C}$ in the trypticase soy broth (Oxoid) and Candida albicans ATCC 10231 were cultured overnight at $37{ }^{\circ} \mathrm{C}$ in the Sabouraud liquid medium (SDB, Oxoid). Suspensions were adjusted to 0.5 McFarland standard turbidity and used as inoculum (15).

\section{Screening for Antimicrobial Activity}

The in vitro inhibitory activity of propolis was investigated by the disc diffusion method. The inhibitory activity of the propolis was detected as a clear zone around the discs. The antimicrobial screening was performed using Mueller-Hinton
Agar, (MHA, Oxoid) supplemented with 5\% defibrinated sheep blood for bacteria and Sabouraud Dextrose Agar (SDA, Oxoid) for yeast (16). Propolis solutions were impregnated on antimicrobial susceptibility discs of $6 \mathrm{~mm}$ diameter ( $20 \mu \mathrm{L}$ per disc) and discs were left to dry four hours (15). Clear zones around the discs were measured after $24 \mathrm{~h}$ of incubation at $37^{\circ} \mathrm{C}$ for bacteria and $48 \mathrm{~h}$ for Candida albicans at $25^{\circ} \mathrm{C}$. The susceptibility of the microorganisms was also tested with commercial discs of ampicillin (10 $\mathrm{\mu g}$-Oxoid) as a positive control and the $\% 80$ ethanol solution as a negative control. All tests were performed in duplicate.

\section{Determination of Minimum Inhibitory Concentrations}

Minimum inhibitory concentrations (MIC) have been determined by microbroth dilution method using 96-well microplates. At this stage, the ethanol-free propolis extract was dissolved with $10 \%$ dimethylsulfoxide (DMSO) and the concentration was adjusted to $400 \mu \mathrm{g} / \mu \mathrm{L}$.

Initially, all wells were filled with $95 \mu \mathrm{L}$ liquid medium [Mueller-Hinton Broth (Oxoid) for bacteria and Sabouraud Dextrose Broth (Oxoid) for yeast] and $5 \mu \mathrm{L}$ inoculum. Then, 100 $\mu \mathrm{l}$ DMSO extracted propolis sample $(400 \mu \mathrm{g} / \mathrm{mL})$ was added to the first well. Afterwards, half of the liquid medium-extract mixture in the first well was transferred to the second well and this process was repeated up to $7^{\text {th }}$ well. Thus, the 200 $\mu \mathrm{g} / \mu \mathrm{L}$ starting concentration of propolis sample was diluted in half at each step.

MIC was defined as the lowest concentration which provides complete inhibition on the microbial growth after incubation. MIC values for propolis against the tested strains were determined from 12.5 to $200 \mu \mathrm{g} / \mathrm{mL}$ (17). All tests were performed in duplicates.

\section{RESULTS}

\section{Chemical Composition of Propolis}

In the present study, the chemical content of a propolis sample obtained from Hakkari province was determined with GCMS. The ratio of individual compounds varied in the propolis sample (Table 1). Consequently, we found that the sample was rich in hydrocarbons (3.06\%), aliphatic acids and their esters (10.49\%), cinnamic acids and their esters (0.57\%), flavonoids (23.83\%), alcohols and terpenes (3.19\%), aromatic acids $(0.44 \%)$ and ketones (1.22\%).

Heneicosane, nonadecane, pentacosane, cyclohexadecane, tricosene, docosane, eicosane compounds from hydrocarbons; palmitic acid, ethyl oleate, octadecanoic acid, decanedioic acid compounds from aliphatic acids and their esters; cinnamic acid, ferulic acid from cinnamic acids and their esters; pinostrobin chalcone, pinocembrin, chrysin compounds from flavonoids; $\beta$-eudesmol, guaiol, 2-methoxy-4-vinylphenol, I-limonene, a-muurolene, farnesol, $\gamma$-terpinene, $\beta$-myrcene, $a$-pinene compounds from alcohols and terpenes; benzoic acid, propanoic acid, 3,4-dimethoxycinnamic acid compounds from aromatic acids; 2 -nonadeca- 
none, 2-pentadecanone compounds from ketones were determined in the propolis sample by GC-MS. The ratio of these individual compounds varied in propolis sample. Among them, pinostrobin chalcone, pinocembrin, chrysin and ethyl oleate were detected at high concentrations; $8.85 \%, 9.16 \%$, $5.82 \%, 8.15 \%$, respectively.

\section{Antimicrobial Activity and Minimum Inhibition Concentration} The antimicrobial activity of propolis were tested against six gram positive (Bacillus cereus, Bacillus subtilis, Corynebacterium diphtheriae, Enterococcus faecalis, Staphylococcus aureus, Staphylococcus epidermidis), three gram negative bacterial strains (Escherichia coli, Klebsiella pneumoniae, Pseudomonas aeruginosa) and one yeast like fungi (Candida albicans). The disc diffusion method was used to determine the antimicrobial activity. The diameters of inhibition zones and minimum inhibition concentrations (MICs) results are illustrated in Table 2. The minimum inhibitory concentration against microorganisms ranged from 25 to $200 \mu \mathrm{g} / \mathrm{mL}$.

\section{DISCUSSION}

Physical appearance and chemical composition of propolis differs depending on seasonal, geographical and botanical factors but it generally contains 50\% resin and vegetable balsam, 30\% wax, $10 \%$ essential and aromatic oils, $5 \%$ pollen and $5 \%$ various other substances. So far, more than 300 compounds, such as polyphenols, terpenoids, steroids, sugars and amino acids were detected in raw propolis (18). However, many studies have reported that the flavonoids present in the propolis are responsible for its biological activities (19-23).

Several studies have been carried out to investigate the chemical content of propolis collected from many different regions using different techniques (24-26). Congruent with existing studies (24), our data showed higher rates of flavonoids found in almost all propolis samples from many different geographical regions. Celemli (24) has reported compounds belong to alcohols, aldehydes, aliphatic acids and their esters, carboxylic acids and their esters, cinnamic acids and their esters, ethers, flavo-

Table 1. Chemical content of a propolis sample from Hakkari province of Turkey

\begin{tabular}{|c|c|c|c|c|c|}
\hline Compounds & $\mathbf{R T}(\min )$ & $\%$ TIC & Compounds & RT(min) & $\%$ TIC \\
\hline Hydrocarbons & & & Alcohols and Terpenes & & \\
\hline Heneicosane & 18.44 & 0.38 & $\beta$-Eudesmol & 17.09 & 1.17 \\
\hline Nonadecane & 17.29 & 0.21 & Guaiol & 15.59 & 0.35 \\
\hline Pentacosane & 20.35 & 0.33 & 2-Methoxy-4-vinylphenol & 10.90 & 0.09 \\
\hline Cyclohexadecane & 18.26 & 0.19 & I-Limonene & 6.53 & 0.11 \\
\hline Tricosene & 19.30 & 0.3 & a-muurolene & 13.74 & 0.01 \\
\hline Docosane & 19.41 & 0.58 & Farnesol & 14.62 & 0.64 \\
\hline Eicosane & 17.32 & 1.07 & ү-Terpinene & 4.91 & 0.01 \\
\hline Aliphatic acids and their esters & & & $\beta$-Myrcene & 10.25 & 0.52 \\
\hline Palmitic acid & 17.90 & 1.15 & a-Pınene & 4.92 & 0.29 \\
\hline Ethyl Oleate & 18.82 & 8.15 & Aromatic acids & & \\
\hline Octadecanoic acid & 18.93 & 0.71 & Benzoic acid & 9.22 & 0.24 \\
\hline Decanedioic acid & 20.65 & 0.48 & Propanoic acid & 11.25 & 0.03 \\
\hline Cinnamic acids and their esters & & & 3,4-Dimethoxycinnamic acid & 17.64 & 0.17 \\
\hline Cinnamic acid & 13.29 & 0.45 & Ketones & & \\
\hline Ferulic acid & 17.57 & 0.12 & 2-Nonadecanone & 18.51 & 0.36 \\
\hline Flavonoids & & & 2-Pentadecanone & 18.55 & 0.86 \\
\hline Pinostrobin chalcone & 20.24 & 8.85 & & & \\
\hline Pinocembrin & 21.02 & 9.16 & & & \\
\hline Chrysin & 22.61 & 5.82 & & & \\
\hline
\end{tabular}

TIC: total ion current; RT: retention time 
Table 2. Diameters of inhibition zones and minimum inhibition concentrations

Diameters of inhibition zones $(\mathrm{mm})$

\begin{tabular}{lccc}
\hline Microorganisms & Propolis & Ampicillin & MIC $(\boldsymbol{\mu g} / \mathbf{m L})$ \\
\hline $\begin{array}{l}\text { Staphylococcus aureus } \\
\text { NCTC } 10788\end{array}$ & $18 \pm 3$ & 23 & 25 \\
\hline $\begin{array}{l}\text { Staphylococcus } \\
\text { epidermidis }\end{array}$ & $16 \pm 2$ & 13 & 50 \\
\hline
\end{tabular}

\begin{tabular}{lccc}
\hline $\begin{array}{l}\text { Corynebacterium } \\
\text { diphtheriae }\end{array}$ & $17 \pm 1$ & 17 & 50 \\
\hline $\begin{array}{l}\text { Enterococcus faecalis } \\
\text { NCTC } 12697\end{array}$ & $14 \pm 2$ & 21 & 100 \\
\hline $\begin{array}{l}\text { Bacillus cereus ATCC } \\
10876\end{array}$ & $19 \pm 1$ & 18 & 25 \\
\hline
\end{tabular}

\begin{tabular}{lccc}
\hline Bacillus subtilis & $20 \pm 2$ & 21 & 25 \\
\hline $\begin{array}{l}\text { Escherichia coli NCTC } \\
9001\end{array}$ & $10 \pm 2$ & - & 200 \\
\hline
\end{tabular}

\begin{tabular}{lccc}
\hline Klebsiella pneumoniae & - & - & - \\
\hline $\begin{array}{l}\text { Pseudomonas } \\
\text { aeruginosa NCTC }\end{array}$ & $9 \pm 2$ & 9 & 200 \\
12924 & & & \\
\hline
\end{tabular}

\begin{tabular}{llll}
\hline Candida albicans & $13 \pm 1$ & - & 100 \\
ATCC 10231 & &
\end{tabular}

MIC: minimum inhibition concentration

noids, hydrocarbons, ketones and terpenes in different propolis samples. The same group has also reported that flavonoid content correlates inversely with hydrocarbon and aliphatic acid contents. Likewise, it is stated that the basic structure of the samples collected from Turkey (Bursa) and Bulgaria is similar in flavonoids, pinocembrin and pinobanksin, the main content the samples collected from İzmir was 3,4-dimethoxycinnamic acid (25). On the other hand, it has been reported that the propolis samples collected from Hatay, Adana and Mersin Provinces of Turkey contain aromatic acids, terpenoids, hydrocarbons, fatty acids, alcohols and many other chemical compounds (26). Contrary to our work, Sahinler and Kaftanoğu (26) have not reported any flavonoid group compounds in the propolis samples used in their study.

According to our results in the Table 2; ethanol extracts of the propolis from Hakkari showed antibacterial activity against all target strains, except Klebsiella pneumoniae. In addition, it showed antifungal effect against $C$. albicans. The results of in vitro antimicrobial assay indicated that our propolis sample inhibits the growth of gram positive bacteria better than gram negative bacteria studied. Our results are in agreement with the findings of Stepanovic et al. (27). Many studies have shown that gram positive bacteria are more susceptible to the antimicrobial effect of propolis than gram negative bacteria $(28,29)$. Silici and Kutluca (16) studied the antimicrobial activity of propolis samples collected by three different races of bees against $S$. aureus, E. coli, P. aeruginosa and C. albicans and found that their propolis samples show strong activity against gram positive cocci $(S$. aureus), but had low activity against gram negative bacteria ( $E$. coli and P. aeruginosa) and yeast (C. albicans). Similarly, Daugsch et al. (30) investigated the antimicrobial activity of six propolis samples against Staphylococcus aureus ATCC 259232. As a result, they reported that the activity grades of six different samples were related to the propolis chemical content and botanical origin of their samples. In a different study, the antimicrobial activity of Tabora and Iringa propolis against gram positive and gram negative bacteria was compared. Researchers reported that propolis samples contained flavonoids, but the activity of the propolis from Tabora was higher than that of propolis from Iringa (31). Gao et al. (32) reported that the pinocembrin (5,7-dihidroksiflavanon) is a compound that can be found in very high concentrations in propolis and, is responsible for antimicrobial activity of propolis. Accordingly, antimicrobial activity of the propolis sample we investigated can be related to the rate of this compound.

The results of our study show that, Hakkari-Turkey propolis has weaker antimicrobial effect compared to ampicillin, but it has a broader spectrum. These findings are also consistent with a previous study. Kalogeropoulos et al. (18) has determined chemical composition and antimicrobial properties of propolis from Greece and Cyprus and they demonstrated that propolis inhibitory spectrum is broader and its activity stronger even at very low concentrations compared to nisin. The main reason for these effects could be the fact that propolis contains many different components which act synergistically while nisin has only one ingredient.

The present study is the first to investigate antimicrobial effect of a propolis sample collected from Hakkari province of Turkey. Our results have showed that propolis from this region contain flavonoids in higher ratio than the other common bioactive compounds such as hydrocarbons, aliphatic acids and their esters, cinnamic acids and their esters, alcohols and terpenes, aromatic acids and ketones. Therefore, propolis from this region is expected to have different biological activities, besides having antimicrobial effect. Hence, it could be concluded that our results support the present usage of propolis as a therapeutic agent in alternative medicine. However, individual isolation of its bioactive substances is necessary in order to explain the full mechanism of propolis action on pathogenic microorganisms.

\section{REFERENCES}

1. Kourkoutas $\mathrm{Y}$, Chorianopoulos N, Karatzas KAG, Banat IM. Bioactive Natural Products 2016. Biomed Res Int 2016; 1-2. [CrossRef]

2. Possamai MM, Honorio-Franca AC, Reinaque APB, França EL, Souto PC. Brazilian propolis: a natural product that improved the fungicidal activity by blood phagocytes. Biomed Res Int 2013; 2013: 541018. [CrossRef] 
3. Falcão $\mathrm{SI}$, Vale N, Cos P, Gomes P, Freire C, Maes L, Vilas-Boas M. In vitro evaluation of portuguese propolis and floral sources for antiprotozoal, antibacterial and antifungal activity. Phytother Res 2014; 28(3): 437-43. [CrossRef]

4. de Groot AC. Propolis: a review of properties, applications, chemical composition, contact allergy, and other adverse effects. Dermatitis 2013; 24(6): 263-82. [CrossRef]

5. Madrigal-Santillán E, Madrigal-Bujaidar E, Álvarez-González I, Sumaya-Martínez MT, Gutiérrez-Salinas J, Bautista M, et al. Review of natural products with hepatoprotective effects. World J Gastroenterol 2014; 20(40): 14787-804. [CrossRef]

6. Keskin N, Hazir S, Baser KHC, Kurkcuoglu M. Antibacterial activity and chemical composition of Turkish propolis. Z. Naturforsch C 2001; 56 (11-12): 1112-5. [CrossRef]

7. Koru O, Toksoy F, Acikel CH, Tunca YM, Baysallar M, Guclu AU, et al. In vitro antimicrobial activity of propolis samples from different geographical origins against certain oral pathogens. Anaerobe 2007; 13(3): 140-5. [CrossRef]

8. Kurek-Górecka A, Rzepecka-Stojko A, Górecki M, Stojko J, Sosada $M$, Świerczek-Zięba G. Structure and antioxidant activity of polyphenols derived from propolis. Molecules 2013; 19(1): 78-101. [CrossRef]

9. Bayram S, Ecem Bayram N, Gerçek YC, Öz GC, Sorkun K. Anticytotoxic and antimutagenic effects of propolis on human lymphocytes in vitro. Mellifera 2016; 16 (2): 38-46.

10. Woo CG, Kang JS, Kim HJ, Kim YJ, Han B. Treatment of air filters using the antimicrobial natural products propolis and grapefruit seed extract for deactivation of bioaerosols. Aerosol Sci Technol 2015; 49(8): 611-9. [CrossRef]

11. Türkez H, Geyikoğlu F, Yousef MI, Toğar B, Vançelik S. Propolis alleviates 2, 3, 7, 8-Tetrachlorodibenzo-p-dioxin-induced histological changes, oxidative stress and DNA damage in rat liver. Toxicol Ind Health 2013; 29(8): 677-85. [CrossRef]

12. Ecem Bayram N, Karadayı M, Güllüce M, Bayram S, Sorkun K, Cevahir Öz G, et al. Genotoxic and antigenotoxic evaluation of propolis by using in vitro bacterial assay systems. Mellifera 2015; 15(1): 29-36.

13. Seda Vatansever $\mathrm{H}$, Sorkun $\mathrm{K}$, Ismet Deliloglu Gurhan $\mathrm{S}$, Ozdal-Kurt F, Turkoz E, Gencay O, et al. Propolis from Turkey induces apoptosis through activating caspases in human breast carcinoma cell lines. Acta Histochem 2010; 112(6): 546-56. [CrossRef]

14. Uzel A, Sorkun K, Oncag O, Çogulu D, Gencay O, Salih B. Chemical compositions and antimicrobial activities of four different Anatolian propolis samples. Microbiol Res 2005; 160(2): 189-95. [CrossRef]

15. Kartal M, Yildiz S, Kaya S, Kurucu S, Topcu G. Antimicrobial activity of propolis samples from two different regions of Anatolia. J Ethnopharmacol 2003; 86(1): 69-73. [CrossRef]

16. Silici $S$, Kutluca $S$. Chemical composition and antibacterial activity of propolis collected by three different races of honeybees in the same region. J Ethnopharmacol 2005; 99(1): 69-73. [CrossRef]
17. Adıgüzel A, Hakan Ö, Münevver S, Medine G, Atalay S, Hamdullah $\mathrm{K}$, et al. Antimicrobial and antioxidant activity of the essential oil and methanol extract of Nepeta cataria. PJM 2009; 58(1): 69-76.

18. Kalogeropoulos N, Konteles SJ, Troullidou E, Mourtzinos I, Karathanos VT. Chemical composition, antioxidant activity and antimicrobial properties of propolis extracts from Greece and Cyprus. Food Chem 2009; 116(2): 452-61. [CrossRef]

19. Burdock GA. Review of the biological properties and toxicity of bee propolis (propolis). Food Chem Toxicol 1998; 36: 347-63. [CrossRef]

20. Benhanifia M, Mohamed WM, Bellik Y, Benbarek H. Antimicrobial and antioxidant activities of different propolis samples from north-western Algeria. Int J Food Sci Technol 2013; 48(12): 2521-7. [CrossRef]

21. Cushnie TT, Lamb AJ. Recent advances in understanding the antibacterial properties of flavonoids. Int J Antimicrob Agents 2011; 38(2): 99-107. [CrossRef]

22. Procházková $\mathrm{D}$, Boušová I, Wilhelmová N. Antioxidant and prooxidant properties of flavonoids. Fitoterapia 2011; 82(4): 513-23. [CrossRef]

23. Daglia M. Polyphenols as antimicrobial agents. Curr Opin Biotechnol 2012; 23(2): 174-81. [CrossRef]

24. Gencay-Celemli O. Chemical classification of propolis samples collected from different regions of Turkey in geographical region base. Hacettepe J of Bio and Chem 2015; 45(1): 49-57.

25. Velikova M, Bankova V, Sorkun K, Popov S. Kujumgiev A. Turkiye ve Bulgaristan kokenli propolis orneklerinin kimyasal bilesimi ve biyolojik aktiviteleri. Mellifera 2001; 1(1): 24-6.

26. Sahinler N, Kaftanoglu O. Natural product propolis: chemical composition. Nat Prod Res 2005; 19(2): 183-8. [CrossRef]

27. Stepanović S, Antić N, Dakić I, Švabić-Vlahović M. In vitro antimicrobial activity of propolis and synergism between propolis and antimicrobial drugs. Microbiol Res 2003; 158(4): 353-7. [CrossRef]

28. Mirzoeva OK, Grishanin RN, Calder PC. Antimicrobial action of propolis and some of its components: the effects on growth, membrane potential and motility of bacteria. Microbiol Res 1997; 152: 239-46. [CrossRef]

29. Drago L, Mombelli B, De Vecchi E, Fassina MC, Tocalli L, Gismondo MR. In vitro antimicrobial activity of propolis dry extract. J Chemother 2000; 12: 390-5. [CrossRef]

30. Daugsch A, Moraes CS, Fort P, Park YK. Brazilian red propolis-chemical composition and botanical origin. J Evid Based Complementary Alternat Med 2008; 5(4): 435-41. [CrossRef]

31. Runyoro DK, Ngassapa OD, Kamugisha A. Antimicrobial activity of propolis from Tabora and Iringa Regions, Tanzania and synergism with gentamicin. J Appl Pharm Sci 2017; 7(1): 171-6. [CrossRef]

32. Gao M, Zhang W, Liu Q, Hu J, Liu G, Du G. Pinocembrin prevents glutamate-induced apoptosis in SH-SY5Y neuronal cells via decrease of bax/bcl-2 ratio. Eur J Pharmacol 2008; 591(1-3): 73-9.[CrossRef] 